\title{
Biblical Deborah and Mary Mitchell Slessor - A Comparison in Time and Space
}

\author{
Ubong E. Eyo \\ Department of Religious and Cultural Studies, University of Calabar, Calabar, \\ Cross River State Nigeria. \\ Email: edisuamerab@unical.edu.ng \\ (Received: May-2020; Reviewed: July-2020; Accepted: July-2020;
}

Avalaible Online: July-2020; Published: August-2020)

cc (i) (8) This is an open access article distributed under the Creative Commons Attribution License cc)

\begin{abstract}
This paper investigates "Biblical Deborah and Mary Mitchell Slessor - A Comparison in Time and Space and Lessons for Contemporary Africa." Worthy of note is the fact that, for some of the religions of the world women are a problem; from time immemorial they have been subordinate to men, second-class in the family, politics and business, with limited rights and even limited participation in worship. This was not different from the epochs of both biblical Deborah (Judges 4-5) and Mary Mitchell Slessor, the White Queen of Okoyong. In the time where patriarchy was the rule of the day, there arose two women at different places, times yet with similar circumstances to salvage the people and bring about God's mission to the human race. Though both operated within the context of the mission of the church, theirs was missio dei not missio ecclesia, because in their age, missio ecclesia used more of patriarchal instruments while mission dei was/is involve in using human and the entire inhabited world (oikoumenē). The peculiar things about the epochs of both Deborah and Mary Slessor are best described in the text, "...in the days of Jael, the roads were abandoned; travelers took to winding paths. Village life in Israel ceased, ceased until I, Deborah, arose, arose a mother in Israel" (Judges 5:6-7). Both characters are worth studying in close comparison with each other, and this is one of the reasons for this paper. Drawing insights from both characters using historical methodology in the study of religion and the Feminist Biblical Hermeneutics of the Reconstruction of Biblical History among other feminist theories as approaches in evaluating Judges $4 \& 5$ and content analysis research methodology in respect of the life of Biblical Deborah and the life of Mary Mitchell Slessor, the work concludes that in the missio dei, God's whose plan is for an egalitarian society uses all genders equally to bring to pass God's mission. The significant of this work lies not only in it providing a tool for further academic research but in the lessons to be drawn for the present political and religious dispensation in Africa in particular and the world in general.
\end{abstract}

Keywords: Feminist, patriarchal culture, Deborah and Mary Slessor 


\section{INTRODUCTION}

"For most of the religions of the world women are a problem; from time immemorial they have been subordinate to men, second-class in the family, politics and business, with limited rights and even limited participation in worship." (Küng, 2005). This is not different from the epochs of both biblical Deborah (Judges 4-5) and Mary Mitchel Slessor, the White Queen of Okoyong. In the time where patriarchy was the rule of the day. Patriarchy is said to be "a system in which the father is the head of the household .... and this can be extended to the entire society where males dominate in all social, political, economical, legal and cultural roles" (Obi, 2018). This is a system where the female gender is considered to be fragile, ignorant beings and inferior to men in all aspects of life. It was in such a time, there arose two women at different places, times yet with similar circumstances to salvage the people and bring about God's mission to the human race. Though both operated within the context of the mission of the church, theirs was missio dei not missio ecclesia, because in their age, missio ecclesia used more of patriarchal instruments while mission dei was/is involve in using human beings and the entire oikoumene. The peculiar things about the epochs of both Deborah and Mary Slessor are best described in the text, "...in the days of Jael, the roads were abandoned; travelers took to winding paths. Village life in Israel ceased, ceased until I, Deborah, arose, arose a mother in Israel" (Judges 5:6-7). Note that,

- roads were abandoned, and so people took winding paths

- Village life was doomed, without joy but tears, pains and agony

- The negative situations were not changed by the patriarchal system but by women Deborah and Mary Slessor respectively

It is in the light of the above, that this paper looks at the role of Deborah, the judge and Mary Slessor, the White Queen of Okoyong, comparing their roles in patriarchal societies of Israel and Okoyong in Western Calabar, Nigeria, with the intent of drawing lessons thereof, especially as it concerns the mission dei. Using the historical methodology in the study of religion and limiting the work to Deborah, the judge and Mary Slessor, the work strikes a balance that having an all-inclusive egalitarian gender equality and sensitive society is not an option but a necessity in fulfilling the missio dei.

\section{Deborah}

In the Protestant Scripture, two women are named Deborah, the first being the nurse of Rebekah who accompanied Rebekah from Bethuel in about B.C. 2023 to her matrimonial home. She died at great age and was buried near Bethel under the oak called Allon-bachuth (oak of weeping) (Gen 24:59 \& 35:8). It is good to note that Nurses were "held a high and honourable place in ancient times, and especially in the East (2 Kings 11:2), where they were often the principal members of the family (2 Chron 22:11)." (McClintock, 1981). The second Deborah is the one recorded as the wife of Lapidoth, a prophetess and judge (Judges $4 \& 5$ ). There is yet a third Deborah mentioned in the Christian holy writ which is found in the Roman Catholic apocryphal work of Tobit, where she is said to be "the grand-mother of Tobit; or according to the New English Bible (NEB) translation, which follows Sinaiticus, she was his greatgrandmother (Tobit 1:8)." (Seale, 1979). The Deborah of our reflection is the one recorded in the Book of Judges chapter four and five. 
Etymology of the Name: The name Deborah דברה (deboraah) is identified with bee and both of them are from the Hebrew word (daabaar)* which means word, speaking, speech, thing, etc. In some parlance, bee is associated with the word דבך (daabaar)* and called 'a speaker' because of the sound bee makes when it flies. This is seems to be an erroneous understanding of the life of bee, because bee is not the only creature that makes a sound, or even buzzes, fly does the same. Therefore "calling a bee but no other insect a talker would show an imprecision that is ultimately foreign to the Hebrew language" (Uittenbogaard, 2014). In the Old Testament times, honey was known as a great source of strength (1Sam 14:27); where milk serves as the nutritional value for infants, honey did the same for adult and the die-hards. Hence, Canaan was said to be a land flowing with milk and honey (Ex 3:8); Yahweh's judgement as well as Yahweh's word were compared to honey in relation to sweetness. Therefore on one hand, Deborah's words and judgements during Israel's warring times may have been likened with the sweetness of honey from bees.

Distinction is made between bees and flies, in respect to bees belonging to the kingdom of Yahweh while flies belong that of Beelzebub (the lord of flies). The difference here is shown in the fact that,

Bees have a house, live in a colony and adhere to central rule. Bees like flowers, make honey, speak a language, care for offspring and are armed. Flies are homeless, aren't social, acknowledge no authority other than themselves, like dung and decaying flesh, make nothing, speak no language (except making noise), don't care for their offspring, and are not armed. (Uittenbogaard, 2014).

Deborah is here likened to a bee positively as bringing strength, joy, army that defeated their enemies, coordinate the lives of the people in the face of danger and threat.

Deborah's Background: After the death of Joshua, the leadership in Israel in the newly settled Promised Land was left in the hands of tribal warriors who were often raised due to circumstantial reasons of war. Theirs was an amphictyony with an expected theocratic rule where leadership was raised circumstantially. This was the era prior to monarchy and the scripture affirms that, "In those days there was no king in Israel; all the people did what was right in their own eyes" (Judg 21:25 NRSV). Politically, Israel had issues to wrestle with. The essence of this was to show that the theocratic people needed a righteous king; for without a king who reigns under the special authority of Yahweh, confusion sets in and everyone did what seems right in his/her own eyes.

In the religious sphere, they did not fare better, because the phrase, 'and Israel did what was evil in the sight of the Lord' $(2: 11 ; 4: 1 ; 6: 1 ; 13: 1$, etc.) was a recurring decimal in almost all the chapters. When Israelites took possession of the Promised Land, they were to exterminate the Canaanites, build up and established a theocratic nation, but when they entered the land, they grew weary of their tasks, and often adopted friendly terms with the Canaanites and sometimes took over their gods. Hence, by way of punishment, they were given over to their enemies, when they repented, the Lord raised up judges, who were saviours and deliverers , upon whom He sent His Spirit, and who delivered the people and the land from oppression. When the judge dies, the people revert to apostasy and the cycle becomes endless. Edward Young therefore rightly points out that we, "in the book of Judges, a period of constant alternation between apostasy and its consequent oppression upon the part of foes, followed by deliverance under a judge" (Young, 1964). This situation set the stage for the institution of prophecy such as under Samuel and the subsequent demand for a human king. It was a cyclic 
situation of apostasy, judgement by Yahweh, cry for deliverance, leader provided and then back to apostasy that Deborah lived..

A Patriarchal World: During the period under review, R. B. Edwards points out that,

Nowhere in the ancient Mediterranean or Near East were women accorded the freedom that they enjoy in modern Western society. The general pattern was one of subordination of women to men, just as slaves were subordinate to the free, and young to old. Women's life centred on marriage, children, and the home (Edwards, 1979).

The Old Testament in its entirety suggests that women faced increasing restrictions on their public and religious roles. At all periods of Israel's history women were legally subject to men, as they were in the ancient world generally. They were valued chiefly as wives and mothers. Prov 31:10-31 paints a vivid picture of the ideal wife (AV "virtuous woman"): while her wisdom, charm, kindness, and fear of the Lord were all mentioned, prime emphasis was on her industriousness and on the credit and profit she brings to her husband (see also Prov 18:22; 19:14; Ecclus 7:19; 26:1-4).

Apart from industriousness, the qualities most frequently admired in women were beauty, quietness ("a silent wife is a gift of the Lord," Ecclus 26:14), modesty, shrewdness, marital fidelity, and fecundity. Abigail is praised for her intelligence and good sense in contrast to her husband's behaviour (1 Sam 25:3,32); and Judith for her wisdom and piety (Jdt 8:8,28-31). Women are prominent in the patriarchal narratives, in some of the early historical books, and in writings named after them (Ruth, Esther, Judith, Susanna). They are least sympathetically portrayed in the Prophets, which compare weak men to women (e.g., Isa 19:16; Jer 51:30; Nah 3:13) and strongly condemn extravagant, drunken, and wanton women (e.g., Amos 4:1; Isa 3:16), and in wisdom literature, both in canonical (e.g., Prov 9:13; 21:9,19; 27:15; Eccl 7:26) and apocryphal literatures. Negative sentiments are particularly common in Ben Sirach (e.g., $25: 16-26 ; 26: 6-12 ; 42: 9-14)$. In the Jewish culture therefore, women only stood not on their strengths but on that of men. They were virtually seen through the lenses of men. It was a males' world! Such was the society in which Deborah, the wife of Lappidoth became a prophetess and a judge.

\section{Deborah's Personal Profile}

A Prophetess: Of the three 'rescuers' of Israel, it is Deborah who is introduced at the beginning, "as soon as the backcloth of Canaanite oppression has been painted in Judges 4:4" (Motyer, 1992). The first thing mentioned about her in the Bible is that she was a prophetess (Judges 4:4). A prophet was seen to be a person of his/her own time with a message for his/her generation. The function of a prophet was not just a long-term prediction. It was often said that he was not a fore-teller, but a forth-teller of the will of Yahweh. This statement is misleading, if it means that the prophet were more concerned with what people ought to do, than with what Yahweh was doing and purposed to do, or that they did not predict the future at all. Their function "was not to plot the future course of history in detail, but to interpret history in terms of the will of Yahweh" (Anderson, 1959).

This was mostly a work for the male folks, and the title ('ish ${ }^{e}$ lohim), that is 'man of God' always goes with that office. A servant was a humble subject whose goal was to accomplish the tasks assigned by his master. Very few women in the scripture were given the office of prophet and one of them was Deborah, others were Anna (Luke 2:36-37) and the four 
daughters of Philip (Acts 21:8-9). God calls women and gives them authority to speak to others on God's behalf. Deborah's case was a prefigure of what God said in Joel that,

Then afterward I will pour out my spirit on all flesh; your sons and your daughters shall prophesy, your old men shall dream dreams, and your young men shall see visions. Even on the male and female slaves, in those days, I will pour out my spirit. (Joel 2:2829 NRSV)

God gave wisdom and instruction to Deborah which enabled her to rule her people effectively; she was God's mouthpiece who trusted and had every confidence in God's word. It is in this vein that Gail Ekanem rightly postulates that, "she was closed to God and gained wisdom from God, and that God also gave her details of the tactics and military strategy that Israel should use in gaining victory over her adversaries" (Ekanem, 2013). It is good to note again what the scripture says about those who prophecy and put our object of study within the same framework that, "those who prophesy speak to other people for their upbuilding and encouragement and consolation. 4 Those who speak in a tongue build up themselves, but those who prophesy build up the church" (1 Cor 14:3-4 NRSV). This may have been one of the things that made Deborah a good judge giving good counsel to the people in their time of perplexity. She edified not only the individuals but the entire community of God's people.

A Family Woman: The second thing the holy writ records in respect of Deborah was her marital status - she was 'the wife of Lappidoth'. Note she was the wife, not a wife of Lappidoth. Like every other great woman in the Bible, she was married, "but her husband is scarcely more than a footnote in the account of how this formidable lady directed, rule and mobilized her people in a time of national emergency" (Motyer, 1992). Deborah's marital life speaks of a woman with a settled home and family, but also one whose family life was not her only concerned. She had the entire community at heart. No wonder she was called, the mother in Israel. Lappidoth needs to be praised, because he did not push the wife into the house, but graciously released her to function in the missio dei in a patriarchal culture. The question is, how many men could have allowed this and not quoted Pauline pastoral 'text of terror' usually cited out of context that,

Let a woman learn in silence with full submission. I permit no woman to teach or to have authority over a man; she is to keep silent. For Adam was formed first, then Eve; and Adam was not deceived, but the woman was deceived and became a transgressor. Yet she will be saved through childbearing, provided they continue in faith and love and holiness, with modesty. (1 Tim 2:11-15 NRSV)

A Judge: In the early patriarchal times the heads of families and the elders of the tribes (which were always men) were the judges (cf. Gen 38:24), and their authority was based on custom. In the wilderness Moses alone was the judge until Jethro suggested a scheme of devolution. On his advice Moses divided the people into groups of thousands, hundreds, fifties, and tens, and over each group a wise and good man was set as a judge. Thereafter only the most important cases were brought before Moses (Ex 18:13-26; Deut 1:9-17). This arrangement ceased to be practicable when the children of Israel settled down in Canaan. In the days of the judges justice was administered by those who had risen by wisdom or valour to that rank (Judg. 4:5). It is sometimes argued that Deborah was not a judge in the sense of settling cases, but this assumption is wrong base on two major premises - verse five of the text speaks contrary to this. It states that, "She held court under the Palm of Deborah between Ramah and Bethel in the hill country of Ephraim, and the Israelites came to her to have their disputes decided." (Judg 4:5-6 NIV); secondly, the word שפת (shaphat) a word with a primitive root meaning 'to judge', i.e. 
pronounce sentence (for or against); by implication, to vindicate or punish; by extension, to govern; passively, to litigate. Therefore to disregard Deborah as a judge and "proposing 'a better title for' her as put forth by Oscar Grether" (Fensham, 1979) is uncalled for. Worthy of note is the fact that, her work extended from judiciary level to that of being a deliverer of her people as could be seen in the text.

A Deliverer: Without any controversy, Deborah served her people as their deliverer from the hands of Jabin, a king of Canaan, who reigned in Hazor and his commander, Sisera who lived in Harosheth Haggoyim. These duo had nine hundred iron chariots, and had cruelly oppressed the Israelites for twenty years. From the intimations which the biblical narrative (especially Deborah's song) contains, and from other circumstances, the Israelites would appear to have sunk into a state of total discouragement under the oppression of the Canaanites, so that it was difficult to rouse them from their despondency, and to induce them to make any exertion to burst the fetters of their bondage. At length Deborah summoned Barak, the son of Abinoam from Kedesh, a city of Naphtali, on a mountain not far from Hazor, and made known to him the will of God that, he should undertake an enterprise for the deliverance of his country. Barak was disheartened but showed confidence in the superior character and authority of Deborah (if she will accompany him to the battle field). Hence his words, "If you go with me, I will go; but if you don't go with me, I won't go." (Judges 4:8 NIV).

If not for God using Deborah, the bondage of Jabin over Israel could have continued unabated. She was a deliverer to her people. Here, the yoke and 'superiority' of patriarchy bowed to proper egalitarian principle of letting the cap rest on the head of whom it fits. Deborah did not just deliver her people from the Canaanite bondage, but she set the stage to deliver her people from the bondage of patriarchy. Thereby, setting an example of deliverance for all other patriarchal communities in the future. She was indeed a deliver in time and space.

\section{Mary Mitchell Slessor}

Background and Personality: The path of honour is not always trod by those who were born into greatness but by those who irrespective of their birth made positive indelible marks in the lives of people. Such could be said of Mary Mitchell Slessor, who was born on December 2, 1848, near Aberdeen, Scotland. She was the second of seven siblings. She came from a poor family background and lost her father and four of her siblings at an early age. By 1859 when she was only eleven years, she began part-time work in a weaving mill and by 1862 was working full-time. She later became very active in church activities and in May 1875 offered her services to the Foreign Mission Board. Her heart was set on Calabar, but so eager was she to be accepted that she said she would be willing to go to any other field. Her personality, and the accounts given of her character and work, made such an impression on the officials that they reported favourably to the Board, and she was accepted as a teacher for Calabar. After training in Edinburgh, she set sail in the S.S. Ethiopia on 5 August 1876, and arrived at Old Calabar in West Africa in September of the same year.

It is good to note that her new home, Calabar was a patriarchal community under the servitude of some obnoxious cultural practices which were inimical to human rights. This therefore reduced the quality of the people's life. There was need for a deliverer and there was none vividly available until Mary Slessor, Eka kpukpru owo (the mother of everybody) arose.

Mary Slessor's Legacies: The boldness of traversing the jungle of Africa by this Scottish woman need not go uncelebrated. In the dark and thick forest of Africa were different customs 
which were inimical to the welfare of human society, and Mary Slessor delivered the people from those customs. Some of her strides included the following:

Inhumation: Among the people Mary worked with, there was a strong belief, like the ancient Egyptians, in a future life beyond the grave. In real sense, what they called 'grave' is a burial chamber made up of different compartments meant for the comfort of the deceased king or chief. It also accommodates his personal attendants and property wherewith he is expected to start another life in the next world. This belief in a future life accounted for the inhumation as part of the funeral rites of men of rank so that the deceased might dwell in comfort beyond, with their servants and wives who must accompany them in the land of the dead. The death of a chief actually spelt doom for his wives and slaves. Mary fought against this and on one of such occasions, it is recorded that the women

Rushed up to her and knelt down, their heads touching the damp ground, 'you have saved our lives...if you had not come, we would all have perished with our chief. How can we thank you? You will always be our mother, and we will be your children (Benge, 2000).

At the end of the Mary Slessor's ministry in Okoyong (in particular) it was recorded that, "no tribe was formerly so feared because of their utter disregard of human life, but human life is now safe. No chief ever died without the sacrifice of many lives, but this custom has now ceased" (Livingstone).

Killing of Twins: Worthy also of note is the people's belief that the birth of twins was a curse to the people and the land. This is contingent on the belief that human beings were not expected to give birth to more than a baby at a time, and that it is only animals that give birth to more than a baby at a time. It was therefore seen as curse rather than a blessing. This way of reasoning may not be unconnected with infant mortality which was prevalent at that time due to poor economy, feeding, hygienic and medical conditions the people found themselves. Since in most cases the babies were dying due to these factors, (though the reasons for the death were unknown to the people, it was rather attributed to the anger of the gods). The people press on in their belief that for a woman to have given birth to twins, "she must have submitted to the desires of a devil and/or must have had sexual intercourse with two men or with evil spirits to have two children at once" (Obinna, 2013).

One of the most notable legacies of which Mary Slessor is known today is her work in saving the lives of twins. In most of her status in Calabar, she is seen carrying twins, the notable Slessor family and the prestigious Twins Club in Calabar owe their lives to her. With the twins and their mothers she saved from the pangs of death, she started a new family whose existence till today bear the indelible mark of her life and name.

Judge: The relationship between the Okoyong people and Mary Slessor grew into such a great union that her influence could not be ignored both at home and abroad. Even the colonial Government of the day acknowledged this special relationship, and when Consular Officers were being appointed for different districts, Sir Claude, the Consul General recognising her unique position and influence, empowered her to do all that was necessary to organise and supervise a native court. He then left her very much to herself, with the result that the inevitable changes were felt all over Okoyong, where they were made through a woman whom the chiefs and people implicitly trusted.

Her position was akin to that of a consular agent, and she conducted all the public affairs of the tribe. She presided over the native court. Cases would be referred to her from Duke Town (the then seeming administrative headquartes), and she would travel over Okoyong to try them, 
taking with her the consular messenger, who carried back her decision to headquarters for official signature.

Mission Work: It needs to be re-iterated that the church has no mission of her own, the church only bows to the mission of God which embraces all facts of human existence and the entire creation. This thought is vividly captured in the words of Benobo F. Fuabara-Manuel that, "the church has no mission of its own but is called to participate in the one mission of God to the world" (2004). Mary Slessor's work in its totality was mission. None was excluded from it teaching of Sunday School and Bible Study, saving the people from obnoxious cultural practices and raising a godly family were all part of God's mission to the world. She preserved lives for God and thus glorified God's name. She was a missionary par excellence.

Marriage: Worthy of note is the fact that Mary Slessor was never married. Not that she had no desire to marry or had no suitor, but when there was a choice to be made between her missionary work and marriage, she chose missionary work at the expense of marriage. Running in her veins was the blood that cried for the salvation of people from cultural and traditional practices which were inimical to the welfare of human society.

\section{Synopsis of Mrs Deborah Lappidoth and Miss Mary Slessor}

A careful juxtaposition of both Mrs Deborah Lappidoth and Miss Mary Slessor, though both were not the same in marital status, age, place of origin and time of operation, one will not fail to see and draw vivid comparison between both characters.

Firstly, it needs to be pointed out that both were females operating in patriarchal culture. In the male dominated environments where being a woman was like playing being a toy in the hands of their male counterparts, these women gave the world the right sense of egalitarianism. They did not set out to enforce the traditional control that was endemic in their societies or engage in feminist politics, but their thoughts, mission, and religion showed that they were advocates of gender equality and social justice.

Secondly, the same spirit that possessed Mrs Lappidoth was what later possessed Miss Slessor in another time and space. It shows God how works in time and space to fulfil missio $d e i$. The spirit of Yahweh wherein Yahweh moves people to serve divine purposes in their milieu irrespective of their gender and cultural background was upon these women in their different ages. The can be easily designated without controversy as missionaries of Yahweh or the Lord's apostles in their ages. Deborah could be so designated an apostle, not because she was sent to another place of people, but because she was sent by Yahweh to fulfil Yahweh's mission among God's people.

Thirdly, a further point of comparison between both characters is the use of 'mother' attached to them. Deborah is called a mother in Israel, while Mary Slessor ' eka kpukpuru owo' (i.e. the mother of everybody). These names came to them because of the help they rendered to the whole community in a patriarchal culture. When the men took the back door, the women came to the fore and rendered the needed help to the people. God is still in the business of raising women to show that God's plan and purpose is an egalitarian community.

\section{Lessons for the Contemporary Society}

In Paul's Epistle to the Corinthian brethren, he pointed out that, "Now these things happened to them as a warning, but they were written down for our instruction, upon whom the end of the ages has come." (1 Cor 10:11). If history is written just for the sake of knowledge 
without application of such knowledge, then the knowledge would have been in vain. Paul's expression can be applied in this work thus,

Firstly, the comparison between Mrs. Deborah Lapidoth and Miss Mary Slessor brings to the fore that female folks have the same potential with male folk and can do the work assigned to the male folk in a patriarchal culture. Secondly, that God's plan is an egalitarian culture not patriarchy. Hence, God decided to use these women in a patriarchal culture to show that both male and female gender are equally important in God's mission. Thirdly, as Africans where patriarchy seems the rule of the day in some quarters, we need to stress that such communities may limit their blessings if their leadership is only concentrated in the hands of patriarchal leaders. Africa in particular will be denying herself of God-given deliverers when they limit themselves to patriarchy. The doors of politics, economics, religion, technology, etc. should also be opened to include the female gender and make the society an egalitarian one, if all African potentials are to be harnessed for the good of African. This is a major point that Deborah and Mary Slessor have to teach Africa.

\section{CONCLUSION}

A juxtaposition of both Deborah the wife of Lappidoth and Marry Slessor shows great similarities not only in their gender role in a patriarchal cultures but throwing the weight that Yahweh uses the male gender as well as the female gender in the missio dei. The fact that God created human beings male and female, equal in status before God and complimentary to each other is an issue that needs to be emphasised and up held in the modern society. Here, male superiority claim has no place; both were deliverers, warriors, judges, family persons, etc. to the people. These jobs are always associated with the male folks but Deborah and Mary Slessor are good examples that these roles are not exclusive rights of the male folks but that any gender can be used by Yahweh to fulfil God's plans. Limiting them to the male folks is limiting the limitless God.

\section{REFERENCES}

Anderson, G. W. (1959). A Critical Introduction to the Old Testament. London: Gerald Duckworth.

Benge, J. \&. (2000). Christian Heroes: Now \& Then Mary Slessor Forward into Calabar. Seattle: YWAM Publishing.

Edwards, R. B. (1979). Women. In G. W. Bromiley (Ed.), International Standard Bible Encyclopedia (pp. CD-Rom). Grand Rapids: Wm. B. Eerdmans Publishing Co.

Ekanem, G. (2013). Bible Women - God's Word Speaks today on Issues facing Women in Africa. Bukuru: African Christian Textbooks.

Fensham, F. C. (1979). The Book of Judges. In G. W. Bromiley (Ed.), The International Standard Bible Encyclopedia (pp. CD-Rom). Grand Rapids: Wm. B. Eerdmans Publishing Co.

Fubara-Manuel, B. F. (2004). In the Missio Dei - Reflecting on the Being and Calling of the Church in the Sovereign Mission of God. Calabar: Presby Press. 
Küng, H. (2005). Women in Christianity. (J. Bowden, Trans.) New York: Continuum.

Livingstone, W. P. (n.d.). Mary Slessor of Calabar: Pioneer Missionary. Retrieved December 15, 2014, from WholesomeWords: www.wholesomewords.maryslessor.org

McClintock, J. (1981). Deborah. In J. McClintock, \& J. Strong, Cyclopedia of Biblical, Theological \& Ecclesiastical Literature (pp. CD-Rom). Grand Rapids: Baker House Co.

Motyer, J. A. (1992). The Message of Judges - Grace Abounding. Leicester: IVP.

Mouton, E. (2012). Reading a Pastoral 'text of terror' in Africa today? 1Timothy 2:8-15 as a context-specific appropriation of the creation story. In H. J. Hendriks et.al. (Ed.), Men in the Pulpit, Women in the Pew? Addressing Gender Inequality in Africa (pp. 115-128). Stellenbosch: SUN MeDIA.

Obinna, E. (2013). Scottish Missionaries in Nigeria - Foundation, Transformation and Development Among the Amasiri (1927-1944). Lampeter: The Edwin Mellen Press Ltd.

Seale, M. (1979). Deborah. In G. W. Bromiley (Ed.), International Standard Bible Encyclopedia - Revised Edition V5.0.1. (pp. CD-Rom). Grand Rapids: W. B. Eerdmans Publishing Co.

Uittenbogaard, A. (2014). Deborah Etymology. Retrieved December 11, 2014, from Abarim Publication: http://www.abarim-publications.com/meaning/deborah.html.

Young, E. J. (1964). An Introdiction to the Old Testament. London: The Tyndale Press. 
Ubong E. Eyo; Biblical Deborah and Mary Mitchell Slessor - A Comparison in Time and Space $\mid 93$ 